\title{
Roundtable - Pentecostalism and Development Practice
}

\author{
Jörg Haustein (ed.), Carole Rakodi (ed.), Daniel Akhazemea, \\ Mike Battcock, Rick James and Claudia Währisch-Oblau
}

\begin{abstract}
This article revisits central questions arising from Pentecostal actors' development practices. These were raised during the final panel discussion of the 2014 GloPent conference on "Pentecostalism and Development". The four panel participants, all development actors from various organisational and religious backgrounds, considered whether Pentecostal approaches to development work are distinctive, as well as identifying various benefits that can be gained from the engagement of Pentecostal churches in development and some challenges that arise during collaboration between development actors and Pentecostal churches. The discussion was conducted through two rounds of statements by the panel participants, complemented by editorial comments and reflections. It concludes that neither the Pentecostal approach to development nor Pentecostal churches' links with development actors are necessarily distinctive. However, more exchanges are needed between Pentecostal organisations and their members, development practitioners working with Pentecostal churches and scholars of the Pentecostal movement to improve development work among Pentecostals, links between Pentecostals and other development actors and scholarly awareness of the most salient issues.
\end{abstract}

Keywords: Pentecostalism, development, DFID, RCCG, INTRAC, United Evangelical Mission.

The GloPent conference on Pentecostalism and Development, which has led to the production of this special issue of PentecoStudies, also featured a panel discussion of experts working in the nexus of Pentecostalism and Development. The panel was chaired by Carole Rakodi and included the following speakers:

- Daniel Akhazemea, principal of Christ the Redeemer College and pastor of the Redeemed Christian Church of God in London, 
one of the largest migrant churches in the UK, which is engaged in development and social activities, in both Nigeria and the UK.

- Mike Battcock from the UK Department for International Development (DFID), who worked on developing a set of "Faith Partnership Principles" to underpin collaboration between DFID and faith groups.

- Rick James of the International NGO Training and Research Centre (INTRAC) in Oxford, who has worked in NGO consulting for more than 20 years and has collected a large corpus of first and second hand experience in development work with Pentecostals.

- Claudia Währisch-Oblau of the United Evangelical Mission, Germany, a communion of different Protestant churches in Africa, Asia and Europe, which is active in contexts where Pentecostal/Charismatic practices and issues of development often overlap.

The speakers were selected on account of their expertise and work in different types of organization. Two members of the panel are associated with faith-based organizations (one mainline and one Pentecostal) and two with secular organizations (one governmental and one non-governmental).

In order to include the panel discussion in this special issue of PentecoStudies, our panellists agreed to contribute to a written revision of our roundtable discussion. We therefore asked them to prepare a short written statement in response to the following two questions, which had been raised in a similar form at the start of our discussion:

1. From your experience, please identify one or two key issues/ challenges that occur when Pentecostal organizations engage in development practices, or when (secular or non-Pentecostal) development organizations and Pentecostals co-operate.

2. Please elaborate on how these issues have been addressed, identifying good practices and perhaps describing one or two examples.

Carole Rakodi and Jörg Haustein responded to these initial statements, in order to draw out some common themes and issues. The roundtable participants were then invited to respond again, to react to the contributions of other panel members and the editors' response. An edited version of this conversation is printed below, together with a brief conclusion. 


\section{Spectacular Success, Dreadful Failure and a Lot of Mediocre In-Between}

\section{Rick James}

Pentecostal churches do not have a great reputation in development circles. Their track record is patchy - a mixture of spectacular success, dreadful failure, and a lot of mediocre work in between. Such churches face numerous challenges, but these are not insurmountable. If these issues are addressed, Pentecostal churches have the potential to make a huge contribution globally. These short reflections are based on my experience with one indigenous Pentecostal church in Africa. They apply to one particular context and the findings are not necessarily representative of Pentecostal churches as a whole.

This church, with which I was closely involved for more than 10 years, was independent of any Pentecostal umbrella denomination. Set up by a Malawian in 1985, it had grown to more than 400 congregations with approximately 50,000 members by 2000 . It became involved in two specific areas of development work: responding to the needs of children living on the streets in Malawi's main urban centres, and food security and HIV-related programmes in rural communities.

The church faced a number of major inter-related issues in its development work:

- It tended to make a theological separation between the spiritual and the developmental. When these did overlap, they sometimes took the form of a prosperity message, the focus of which tended to be on self-interested gain, rather than serving the needs of others, especially the poor.

- Some pastors, being very poor themselves, felt that they should be the first beneficiaries of any practical initiatives. Others did not see ministry to the poor as important and some saw it as a distraction from their religious ministry. Some were jealous of the external funding obtained for the development programme and saw it as a potential way of resourcing other church ministries. In addition, in a religiously conservative context, many were reluctant to talk openly about the use of condoms to prevent HIV transmission.

- Leadership at both the national and congregational levels was individualistic and charismatic, depending on the force of personality and inspirational preaching. There was limited 
supervision and management of individual pastors. There were also few systems for planning. Because the faith that "God will provide" was all-important, budgeting was often viewed as likely to "quench the Spirit".

These issues were addressed through a variety of means, although there has been no once-and-for-all solution for any of them - they are on-going challenges which need constant attention.

- A significant contribution has come through theological teaching - developing a curriculum on "God's Heart for the Poor" and integrating this into the curriculum of the theological training college (from which around 50 pastors graduate each year). This curriculum firmly bases development work in a biblical context, but also introduces development skills (such as participatory exercises with communities) and thinking (such as taking an inclusive approach to collaborating with, influencing, and learning from other denominations, NGOs and government agencies).

- In a leadership-dominated denomination, it has been vital to engage proactively with the founder leader. Board members and the directors of the development work have regular one-to-one meetings to ensure that the top leader knows what is going on and feels ownership of it, by involving him in the governance structures, although not as chair. Those involved in development work have also worked hard to get the second-line leadership the bishops - to visit communities and see the work first-hand. This has inspired them to encourage the work and advocate that the pastors who report to them should support it, although it has proved necessary to keep re-energizing the bishops.

- A social action policy was developed some years ago and formally ratified by the leadership. This gives pastors a clear written mandate to work with communities on development issues and means that the development work has become more embedded in the institutional fabric of the church.

- At a congregational level, staff of the church development arm regularly visit pastors to provide encouragement and ideas. Pastors who are involved in development programmes meet together at the annual general conference, where an afternoon is set aside to report back on progress in social action initiatives, reinforcing their motivation to continue the work. 
The people involved in the development work found that they had to walk a tightrope, fully involving the central church leaders in the programme its vision, implementation and impact - but at the same time, separating management of its finances and strategy from official church structures. They have developed clear policies and systems for using their resources transparently. This has helped to keep clarity of focus on the needs of the poor and to protect resources from being diverted to other church programmes, especially where pastors have limited understanding of the importance of financial systems and those systems are weak.

Ensuring genuine ownership of the development work by the church leaders without them assuming complete control is a complex and on-going task.

\section{Pentecostalism and Conflict Resolution: Are People Traumatized or Demonized?}

\section{Claudia Währisch-Oblau}

I work for a mainline Protestant mission organization, the United Evangelical Mission (UEM). We are a communion of 36 Protestant churches in Africa, Asia and Europe; and since 1996, all our governing bodies have had a two-thirds majority of representatives from the global South. Our understanding of mission is holistic: it comprises evangelism, advocacy, diaconia, development and partnership.

All UEM member churches in African and Asia are strongly challenged by Pentecostalism, either because there are charismatic movements within these churches, or because they are losing many members to the charismatic and Pentecostal churches which are proliferating around them. But we have also started to learn from Pentecostals, particularly when it comes to "enchanted worldviews".

\section{Example 1: North Sumatra}

In North Sumatra, the Batak believe in an evil spirit called Begu Ganjang which can be conjured up by certain rituals and is used by its "owners" to enrich themselves. However, to do so, the spirit needs to take the life of another person.

In one village near Lake Toba, UEM investigated a case in which several babies had died in quick succession. Villagers suspected a Begu Ganjang, but the local Protestant pastor tried to convince them that the children had died due to contaminated water. The villagers did not believe him 
and killed a family of three which was suspected to have "owned" the spirit. The mob was led by church elders from a UEM member church.

Such killings or expulsions of those suspected of dealing with Begu Ganjang have occurred all over North Sumatra, and the teaching of UEM member churches that Begu Ganjang does not exist just led villagers to believe that pastors do not understand their reality. In this situation, one UEM member church decided to adopt a "Pentecostal" approach: they send an "occultism team" into villages where such suspicions arise, drive out the evil spirit, and help the accusers and the accused to reconcile. In the area where this team works, no killings or expulsions have occurred.

\section{Example 2: Eastern Democratic Republic of Congo and Rwanda}

The UEM member churches in Rwanda and Eastern Congo have been severely affected by the Rwandan genocide and the subsequent wars. All have reacted with development and reconstruction projects, particularly in the areas of agriculture and vocational training. The churches are also active in peace and reconciliation work (e.g. through organizing dialogues between soldiers and civilians, or by involvement in the Rwandan gacacas, local courts that seek to achieve restitution rather than punishment). Finally, the churches do a lot of counselling and trauma healing.

At the same time, it is obvious that many UEM church members are seeking deliverance in Pentecostal and charismatic churches. Clearly, trauma healing, restitution, development and reconciliation in line with international concepts do not meet all their needs. For example, observers suggest that the psychotherapeutic paradigm underlying trauma healing is too individualistic and does not fit local cultures; that most trauma healing approaches do not involve the religious beliefs and resources of the patients; and that trauma healing only reaches a very small minority of the people who need it.

In response, UEM member churches in Rwanda and Eastern Congo have started to train pastors and chaplains in the theology and practice of deliverance ministry, and counselling and deliverance are now often used in tandem, even though many psychologists and medical doctors are strongly critical of such practices, claiming that deliverance rituals reinforce trauma; that the externalization of emotions in such rituals is not helpful; and that trauma due to physical violence should not be spiritualized.

The underlying question here is: are people traumatized or are they demonized? The answer will depend on the interpretative paradigm of 
the observer. But could both answers be valid, and what would that mean for church practice?

With these questions in mind and in response to a request from its African member churches, the UEM has started an international discussion and research process on magic, witchcraft, demons and deliverance. The aim is to develop a Protestant theology and practice of deliverance, and therefore a more holistic way of dealing with conflicts and trauma. In this, the UEM churches are learning from Pentecostal and charismatic approaches. For 2016, we are planning an international seminar that will bring together psychologists, psychiatrists and practitioners of deliverance to see whether an integrated approach to trauma healing can be developed and put into practice.

What we have learned in this process is that Protestants use the term "holistic", but work in such a way that spiritual approaches are limited to spiritual problems, and "secular" approaches (diakonia, development, advocacy and trauma healing) to material, social, political and psychological problems. Today, we have realized that where those afflicted see the problem as spiritual rather than political or social, an exclusively "secular" approach will not be accepted. We are therefore considering how "secular" and spiritual approaches to conflict resolution and trauma healing might be reconciled.

\section{Scepticism, Bureaucracy and Proselytism: Pentecostal Churches and Secular Development Agencies}

\section{Daniel Akhazemea}

For more than a decade both anthropologists and development sociologists have been engaged in debates about religion and development. ${ }^{1}$ Based on churches' mission statements and observable practices, some scholars have observed that, especially in the twentieth century, Pentecostalism emphasized spirituality at the expense of human, social and intellectual development. ${ }^{2}$

1. D. Miller and T. Yamamori, Global Pentecostalism: The New Face of Christian Engagement (Berkeley, CA: University of California Press, 2007); G. Ter Haar and S. Ellis, "The Role of Religion in Development: Towards a new Relationship between the European Union and Africa", European Journal of Development Research 8.3 (September 2006), pp. 351-67.

2. Timothy C. Tennet, Theology in the Context of World Christianity (Grand Rapids, MI: Zondervan, 2007), pp. 166-92. 
It has also been observed that in the twenty-first century, Pentecostal denominations across the globe are not only identifying development challenges but are also committed to the transformation of social and political structures in the contexts in which they work. ${ }^{3}$ A typical example is the Redeemed Christian Church of God (RCCG), a wholly indigenous Pentecostal denomination from Nigeria that is now a global missionary player. ${ }^{4}$ Today, many RCCG churches are investing considerable resources in human, social and intellectual development within the communities in which they are located.

For example, in Nigeria, the RCCG and its para-church organizations not only have a powerful missionary drive but are also identifying and prescribing solutions to the myriads of socio-economic, health and educational challenges the church's members and congregations face. ${ }^{5}$

This is also true of the missional thrust of the RCCG and its churches across the nations of the world. ${ }^{6}$ The policy embodies a holistic approach to meeting the spiritual, educational, social and economic aspirations of the communities where the churches are present. In the United Kingdom, for example, social involvement with the communities in which the church's branches are established rank highly in the annual evaluations of the churches. According to the RCCG(UK) annual report of 2013, empirical research is currently being undertaken to determine the economic worth of the social and community projects undertaken by its churches. These community and social projects include recreational and development facilities for young people, including kids' and

3. Afe Adogame, "HIV/AIDS Support and African Pentecostalism: the case of the Redeemed Christian Church of God", Journal of Health Psychology 12.3 (2007), pp. 475-84.

4. RCCG is the fastest growing Pentecostal church in Britain. for further details see Ruth Glendhill, "How Reverse Missionaries Built the UK Fastest-Growing Church”, Christianity Today (2014), www.christiantoday.com/article/how.reverse. missionaries.built.the.uks.fastest.growing.church/37894.htm (accessed 27 of August 2014).

5. Daniel Akhazemea, "Global Missionary Player: The Redeemed Christian Church of God: Her Message of Human Development" in Owe Boersma and Wilfried Neusel (eds), Encounter beyond Routine: Cultural Roots, Cultural Transition, Understanding of Faith and Cooperation in Development (Hamburg: Evangelisches Missionswerk in Deutschland, 2011), pp.53-64, www.emw-d.de/fix/files/doku_5_encounter-beyondroutine2011.pdf.

6. Afe Adogame, "A Walk for Africa: Combating the Demon of HIV/AIDs in an African Pentecostal Church - The Case of the Redeemed Christian Church of God", Scriptura 89 (2005), pp. 396-405. 
youth clubs, development training projects to help communities address various social issues, food banks, advisory services, and many more. Some of these services have been commended by public figures for their contributions to community development and cohesion. For example, during his 59th birthday celebrations at Jesus House, a parish of the RCCG in London, Prince Charles commended the church's engagement with the Prince's Trust.

However, it is imperative to note that, despite the willingness of RCCG churches to partner with the state and secular institutions, most state agencies are sceptical of the competence of religious institutions to undertake development initiatives. Such a disposition appears to arise from a lack of understanding of the religious organizations concerned and of the role of faith leaders in community development. Religious organizations such as churches are hubs of social, cultural and social engagement. Because members of a faith community trust their religious organizations, they have huge stores of social and religious capital. However, even though the importance of churches in community development cannot be over-emphasized, they are mostly ignored. Religious illiteracy is a major constraint, giving rise to deep suspicion by state agencies of churches' motivation for community engagement. The apathy of some state agencies might also be based on fears that Pentecostal denominations might use state resources for proselytizing rather than for community development. In turn, religious organizations' lack of understanding of agencies' procedures and their expectations of secular authorities are also challenges.

From my experiential perspective as a faith leader, I have observed that the bureaucratic processes required by state agencies constitute a major hindrance to the involvement of churches in community development. The various statutory requirements emphasized by state agencies are often regarded by religious actors as cumbersome, demanding and sometimes unimportant. Despite these challenges, there are many opportunities for interaction between churches and state agencies, to foster mutual understanding and collaboration in the development of communities.

It appears evident that education and openness in dialogue between religious organizations and the state would help to develop the mutual trust that can facilitate collaboration between churches and secular agencies. Even though it sometimes appears that secular agencies are concerned about procedures, accountability and sustainability, while the church is concerned with meeting immediate community needs, these 
objectives can be complementary rather than mutually exclusive, as can be recognized in strategic collaborations.

It can be safely said that any effort in mission that does not take human and social development seriously will be short lived, as attested by past revivals which have left few lasting fruits. Pentecostal churches must be bold in their involvement with development goals and challenges through their social responsiveness and resource allocation.

\section{Working Effectively with Faith Groups}

\section{Mike Battcock}

Faith groups are a significant and distinctive part of civil society, with varied beliefs, legitimacy, reach, sustainability, and values. They make an important contribution to poverty reduction through providing services and humanitarian assistance, promoting empowerment and accountability, changing beliefs and behaviours, building support for development and building peaceful states and societies.

In the past, there was an estrangement between faith groups and development donors. Donor governments often avoided the issue of faith and religion. Faith groups felt shut out by development agencies and when they were allowed in, they felt that they had to leave their faith at the door. There was a lack of understanding and empathy between faith groups and governments, donors, secular development organizations, and other parts of civil society. Religion and faith were regarded as inherently contentious and a barrier to development.

To address these issues and strengthen DFID's collaboration with faith groups to transform poor people's lives, a Working Group was established to produce a set of principles on which to base a partnership between the agency and faith groups. DFID undertook a literature survey to identify the evidence available on the role and impact of faith and faith groups in development. It then organized a workshop with more than 40 representatives of faith groups, civil society organizations and academics to identify the key issues and agree on a process for selecting the Working Group. The Working Group was asked to produce a consultation paper, to engage in a dialogue with the wider range of organizations interested in this subject, and to produce a draft Principles Paper. The final version of the Faith Partnership Principles Paper was launched at Lambeth Palace, the London headquarters of the Anglican Communion, in 2012. DFID and the Working Group then produced and agreed a priority action plan. 
The Faith Partnership Principles Paper highlights the need to build a common understanding of the role of faith in development, to document evidence on the distinctive contribution and impact of faith groups, and to create an open and frank forum for debate.

- Building a common understanding of faith and development: The Faith Partnership Principles highlighted that everyone working in development needs to have an understanding of the role played by faiths in the local, national and global contexts. There has subsequently been considerable work to build up a better understanding through regular Working Group meetings with DFID, consultation with DFID country offices and professional cadres, and faith literacy training in the Foreign and Commonwealth Office and DFID. These activities have resulted in a real change in attitude, with most development practitioners now believing that religion is important in development and that they need to understand its role.

- Documenting the impact of faith groups through research: The Faith Partnership Principles highlighted the need for more systematic evidence on the scale and nature of the services provided by faith groups, and the distinctive contributions they make. Members of the Working Group established a community of learning to map the work of faith and inter-faith groups, document the added value and effectiveness of approaches used by faith groups, and produce guidance on evaluating the impact of faith groups' activities. Considerable work to assess the impact of faith on development has been undertaken through the Joint Learning Initiative and the DFID-funded Religions and Development Research Programme at the University of Birmingham, as well as major research programmes at Coventry, Leeds and Edinburgh universities.

- Open and frank debate: A major challenge is to develop ways of working that help faith groups and DFID to identify and discuss areas of difference in constructive ways without threatening wider collaborative work. Efforts to create open and frank fora have included a "Religion and Foreign Policy" Transatlantic Dialogue at the Brookings Institution in 2014; a cross-government workshop on "How Should Governments 'Do' God?”; a Wilton Park conference on "Religion, foreign policy and development: making better policy to make a bigger difference"; and a Faith 
Summit hosted by the Parliamentary Under Secretary of State for International Development, Lynne Featherstone, to discuss female genital mutilation and cutting.

\section{A Fragmented Development Discourse?}

\section{Jörg Haustein and Carole Rakodi}

Panellists' responses to our initial questions were remarkably disparate. For example, they identify different issues as the most important challenges when Pentecostal churches become involved in development activities, independently or in collaboration with others. This may point to a fragmentation of development discourse and suggests a need for further reflection. First, why are their contributions so disparate or heterogeneous? One possibility is that it may not be possible to associate Pentecostalism with a specific approach to development policy or practice. It is also possible that it is simply too soon for a conversation about the engagement of this particular religious movement in development. Or do our respondents have different perspectives arising out of their specific institutional or personal locations, not least as insiders writing about their own organization or outsiders seeking to work with organizations other than their own? Second, one may wonder whether this heterogeneity is a problem or an asset. Is it desirable to pursue further conversation in order to identify more common ground? Or should diverse discussions and views be welcomed in the loosely defined and plural field of development discourse, policy and practice? This special issue seeks to stimulate a conversation about the links between Pentecostalism and development, so these questions directly address the theme from the vantage point of development practice.

We have identified three layers in which our respondents' contributions vary noticeably. A first layer relates to the extent to which they address Pentecostalism as a specific religious movement. Claudia Währisch-Oblau offers the most concrete discussion of Pentecostalism. In her example she characterizes Pentecostalism as a religion compatible with "enchanted world views", which might thereby offer an alternative approach to conflict resolution due to the tradition's closeness to local spirit idioms. Thus she identifies one theological particularity of Pentecostalism as being potentially useful for development practice. Rick James also speaks about one specific Pentecostal church. First, he identifies a number of challenges to development arising from its teaching and characteristics: an emphasis on saving souls (rather than improving 
lives), a rather self-interested prosperity message, and largely unchecked "charismatic leadership". However, he also mentions that a "significant contribution" to church actors' understanding of development issues was made "through theological teaching", although he does not go into detail on the content of this teaching. Daniel Akhazemea, in contrast, does not provide a theological profile of his own RCCG. Running food banks, youth clubs, and community training projects, or seeking to combine its religious mission with human and social development, the RCCG in his account appears similar to any other faith-based organization. Presumably there are specific beliefs and practical resources that are unique to Pentecostalism, or even to the RCCG within the broader range of Pentecostal theologies, which could inform the churches' development activities, but these are not mentioned. Mike Battcock, finally, does not address Pentecostalism specifically, rather subsuming it within faith-based groups in general. Does this imply that there is a one-sizefits-all approach to the role of religions in development, or that there is limited understanding of Pentecostalism in particular within DFID? The contributions to this panel do not, therefore, address the larger question of whether there is (or should be) a specific Pentecostal approach to development. Do Pentecostal responses to development challenges simply mirror those of other faith groups or are there challenges and resources particular to Pentecostalism that both its own members and external experts should take into account?

A second layer of heterogeneity in the responses is that of institutional context and perspective. Mike Battcock speaks from the vantage point of a secular development agency faced with the apparently rather difficult task of integrating a foreign world of religious beliefs and practices with its own perspective on development. His contribution, which describes how policy toward religions is being developed in a specific organization (DFID) and the first actions taken, seems to be primarily aimed at the institution itself. However, in this contribution he says little about DFID's actual interface with faith groups, let alone how they have reacted to the Faith Partnership Principles Paper and DFID's actions. Claudia WährischOblau and Daniel Akhazemea, in contrast, write from the vantage point of religious actors who seek to understand their impact on development practices. Währisch-Oblau speaks for UEM, an international organization of mainline churches which are "strongly challenged by Pentecostalism", whereas Akhazemea speaks from the vantage point of an international Pentecostal church (RCCG). Akhazemea, accordingly, seeks to highlight the potential use of the "religious capital" of Pentecostal churches for 
achieving development objectives, without examining denominational differences within Pentecostalism, while Währisch-Oblau attempts to clear space for the integration of some Pentecostal beliefs in a pluralistic menu of approaches to conflict resolution. Rick James, finally, is mainly concerned with the implications of the organizational characteristics of a particular Malawian church for its role in development, describing how the church has responded to some of the challenges posed by growth and social engagement. The influence of the panellists' different institutional locations on their selection of issues to discuss, their emphases and standpoints do, of course, highlight the plurality of stakeholders and varying viewpoints involved in any potential collaboration between Pentecostal movements and development agencies.

A third and final layer of disparity is also linked to the institutional perspective of the contributors, in this instance pertaining to the kind of change that is aimed for. What do our respondents seek to achieve and who do they consider responsible for improving the interface between Pentecostalism and development efforts? For Daniel Akhazemea the responsibility lies especially with those governmental and non-governmental actors which seek to work with Pentecostal churches. In the case of the RCCG, he suggests, many practical programmes have already been established, and the church now aims to serve the local communities in which its churches are located, as well as the wider society, so that Pentecostal development efforts can really make a difference. In order for this to happen, according to Akhazemea, secular and non-Pentecostal agencies need to overcome their scepticism and learn to understand Pentecostals. Mike Battcock seems to think along similar lines: development agents need to make room for faith-based initiatives by increasing their own religious literacy, funding research on the issue and engaging in dialogue. Perhaps the change he seeks is less about helping faith actors with their development efforts, and more about achieving "secular" development aims and implementing relevant projects through various types of collaboration with faith groups. In contrast to Akhazemea and Battcock, Rick James suggests that in order to make a "huge contribution globally", Pentecostal churches must address shortcomings in their development outlook as well as their organizational structure. The roles that Pentecostal churches might play and the potential for collaboration or conflict with other religious and secular agencies engaged in development will depend on the model of development each espouses, the priorities that model implies, and their views about the most appropriate means of achieving the organization's 
objectives. Claudia Währisch-Oblau seems to take a middle position with her argument for "holistic development", implying that it is possible to "reconcile 'secular' and spiritual approaches". However, there are also likely to be tensions.

These three layers of disparity illustrate why conversations on Pentecostalism and development are complex and may be inconclusive. We therefore invited the panellists to contribute to a second round of discussion, in which they could engage with each other's contributions by considering the following three questions:

1. Are there aspects of Pentecostal belief or organization that imply that Pentecostal churches have or require a distinct approach to development? Do these indicate potential or problems? If so, how can positive outcomes be realized or problems tackled?

2. How does your own organization need to change to further cooperation between Pentecostals and development actors?

3. What change(s) do you see as the most important and urgent overall?

\section{Response}

\section{Claudia Währisch-Oblau}

The first question is too general. Neither Catholic nor Protestant churches have or require "a distinct" approach to development, so why should the very disparate Pentecostal churches have one? I think that several layers of distinction are necessary:

1. What is the socio-economic status of the actors? A small backyard church in a poor neighbourhood in Accra, whose members pool their meagre resources to make their way out of extreme poverty without any outside help, will have a very different approach from a rich megachurch which has mostly middle and upper class members who might seek to do something "for" the poor.

2. What are the underlying theologies? Not all Pentecostals preach a prosperity gospel, but whether or not that shapes the faith of a church is likely to make a difference to the development approach it adopts or advocates. In addition, the way in which a problem is described by the persons affected - in a moral, social, political or spiritual paradigm - will shape how a church deals with the problem. As I have said above, I think that neither secular nor many Christian development organizations are open to looking 
at problems from a moral or spiritual perspective, whereas the more moral and/or spiritual approach of Pentecostal churches might enable a problem to be tackled more effectively.

3 . Is the church in question an established denomination with stable governing structures, a founder-owned megachurch, or an emerging movement with a more charismatic style of leadership?

4. And finally, what are local concepts of "good living" and how are they changing? I believe that such concepts may be quite similar across denominational divides, but the strategies on how to get there might differ.

The second question does not really pertain to the United Evangelical Mission. We deal mostly with theological, educational and organizational issues in our partner churches, which are mainline Protestant churches influenced by the charismatic movement. So we are primarily interested in learning together how to facilitate various development goals in our partner churches, rather than furthering contacts between Pentecostal churches and other development organizations.

In response to the third question, I think what is most urgent is true dialogue. Development organizations need to respectfully listen to people of faith and try to understand their point of view without judging how problems and problem-solving strategies are described in faith paradigms. Similarly, the churches need to listen respectfully to secular development agencies and try to understand them without judging. Such dialogues will likely not work on a global and abstract scale, but they can be helpful in concrete contexts and in the face of concrete issues. I hope that the outcome of such dialogues would be new and integrated approaches.

I realize that this will not be easy. On the one hand, development organizations are under pressure to show quick results, and this does not allow for longer processes of searching for the right way. On the other hand, churches tend to be fully occupied with their own work and find it difficult to make time for processes of dialogue from which they do not see any immediate benefits.

\section{Response}

\section{Daniel Akhazemea}

With regard to the first question about whether there are specific Pentecostal beliefs and practices that give rise to distinct approaches in 
development, it is important to note that Pentecostal beliefs and practices are not the same among all actors within that stream of the Christian faith. The loose thread that appears to hold them together is perhaps the belief in the authority of the Bible and the practical presence of the workings of the Holy Spirit, as demonstrated through healing, miracles, glossolalia, deliverance, prosperity, and the freedom of the Spirit. While "enchantment" may be involved, this is not present to the same degree in different strands within the Pentecostal movement.

The organizational structures of Pentecostal churches are also diverse. Many, both small and mega-churches, are characterized by a "one-man" leadership style, but others have an organizational structure similar to the traditional or denominational Pentecostal churches. Here, leadership is not tied to the charisma of the leader, who may be elected or appointed based on specified guidelines.

Obedience to Jesus' command to love our neighbour and provide for the less privileged is central to the RCCG approach to development. It may be true that within the Pentecostal frame of reference, development is not seen as an end in itself but rather as a means of extending Christ's love to others and providing an invitation for them to embrace that love. Thus while the envisioned end benefits are clearly the same (the well-being of the recipients), Pentecostals would understand their efforts as the enlargement of the kingdom of God on earth.

This is perhaps the reason for the divergence in the expectations between secular agencies and faith-based organizations. It is important for faith-based practitioners to seek to understand the rationale underlying the provision of development resources by secular agencies, and to engage with their objectives, which in practice may not be very different from those of faith-based organizations. So it would appear to me that while the approaches of secular and religious organizations may be different, their objectives are more similar than is often realized.

In response to the second question about changes to my organization to further cooperation between Pentecostals and the development actors, I would emphasize the importance of education about the need for cooperation between the Pentecostal churches and secular agencies. This has been the strategy of our organization for several years, in pursuance of joint project initiatives with governmental agencies and other churches. The Church undertakes various training programmes each year, drawing facilitators from government and development agencies. These training events help to broaden the Church's understanding of governmental expectations and also secular agencies' understanding of the work of the 
Church. It must be stated that such mutual awareness and understanding is necessary to avoid the danger that each perceives its own perspective as the only or best one. Such dialogue will also go a long way to remove mutual suspicion as to the motivations of the actors involved, and thereby to enhance the benefits of cooperation.

Finally, in response to the third question, I think the most important and urgent changes have to do with perception and orientation. The ideals of the development agencies and most Pentecostal churches are not as divergent as Jörg Haustein and Carole Rakodi suggest. The well-being of those in need is the goal of both secular developmental agencies and the Pentecostal churches. The challenge may rather lie in the differences between approaches to achieving this goal. There is therefore a need for openness, honesty and willingness to change on both sides. It will be difficult for a Pentecostal church to completely strip spiritual benefits from any development initiative. However, the Pentecostal churches must also be aware that spirituality is not the basis for secular development initiatives, so there is a need to continue the dialogue, in order to explain various practices and their underlying assumptions to one another. Such dialogue is not only possible but also necessary. Only then can both types of organization make the changes needed to fulfil their aim of ensuring that the intended beneficiaries (the less privileged) receive the help and support they need, which cannot be provided solely by either the state or the church. Such an open dialogue will eliminate the suspicion and fear that may exist on both sides.

\section{Conclusions}

\section{Carole Rakodi and Jörg Haustein}

We would like to thank Claudia Währisch-Oblau and Daniel Akhazemea for engaging with our questions in their responses and clarifying various issues they have raised. We also thank Rick James and Mike Battcock, who commented on our remarks and questions in the form of shorter notes, the content of which is included in our final observations.

Our response to the initial four contributions identified considerable disparities in panellists' responses to the questions we posed, leading us to question whether it is possible or sensible to consider Pentecostalism as a distinctive and unified entity when considering the role of Pentecostal churches in development discourse and practice. The practitioners, it seems, were less surprised by this plurality of perspectives and interests, given the original selection of panellists with different viewpoints and 
institutional locations, including the varying nature and frequency of their interaction with Pentecostal churches in the course of their work.

As both Daniel Akhazemea and Claudia Währisch-Oblau point out, Pentecostalism itself is diverse, requiring a nuanced and plural approach. Akhazemea contends that Pentecostal ideas and practices are only held together by a "loose thread" of "belief in the authority of the Bible and the practical presence of the workings of the Holy Spirit", while there is an even greater diversity of organizational structures. Währisch-Oblau agrees, adding further layers of diversity relating to the socio-economic background of the actors, the local contexts changing under global influences in which they operate, and the corresponding concepts of "good living".

In addition to the plurality of Pentecostalism itself, it is also difficult to distinguish between Pentecostals and other Christian actors in the development sector. Claudia Währisch-Oblau thus points to overlaps between Pentecostal theologies and practices and those of mainline churches which have experienced charismatic movements, although the issues those based in the South face may be quite different from those faced by their partner churches in the West. Similarly, according to Rick James, the development-related "theological teaching" offered by the church in Malawi he described was rooted in a mainstream theology of concern for the poor, rather than having specifically Pentecostal features.

James also alerted us to another danger: that framing the question as Pentecostalism and development might encourage the actors to be pigeonholed: Pentecostals on the one hand and non-Pentecostal development agents (Christian or secular) on the other. This might even lead to an implicit assumption that someone working for a secular development would automatically approach Pentecostalism as an outsider, with no personal connections. Not only are many of those working for secular agencies affiliated to religious bodies, increasingly development agents are developing an understanding of and working together with religious actors at various levels. Moreover, as Daniel Akhazemea points out with regard to his own Church, development goals and practices have been absorbed into Pentecostal teaching, so that the real issue at stake is less a religious-secular divide in orientation than how to overcome various practical and bureaucratic hurdles in aligning organizational practices.

What then can we conclude from this conversation? As Mike Battcock emphasized in a brief response to our first question, "context is everything": while there is an "overarching need to build up an understanding of the complexity of faith and religion", such "a common 
understanding requires specific and targeted information on the role of faith in different contexts." This is why all four contributors reiterated again and again the need for sustained dialogue between the actors involved in a given context. No academic deliberation about Pentecostalism and development can replace such direct engagement. The by now substantial research on Pentecostalism can certainly provide development actors with information about Pentecostalism's theological, practical and organizational plurality. Yet as our contributors have shown, dialogue may significantly add to that. It not only brings together various perspectives, it also shapes and alters them. Not only is this kind of dialogue already taking place, there are also more points of contact and overlap than the academic study of Pentecostalism has recognized in the past. Therefore it is our hope that, in the future, there will be more forums for exchange between practitioners and academics, in which the concrete experiences and perspectives of Pentecostals who are engaged in development work can further inform the academic study of the movement and vice versa. 